\title{
THE EFFECT OF MONETARY POLICY AND INSTITUTIONAL ENVIRONMENT ON BANK LENDING IN NIGERIA
}

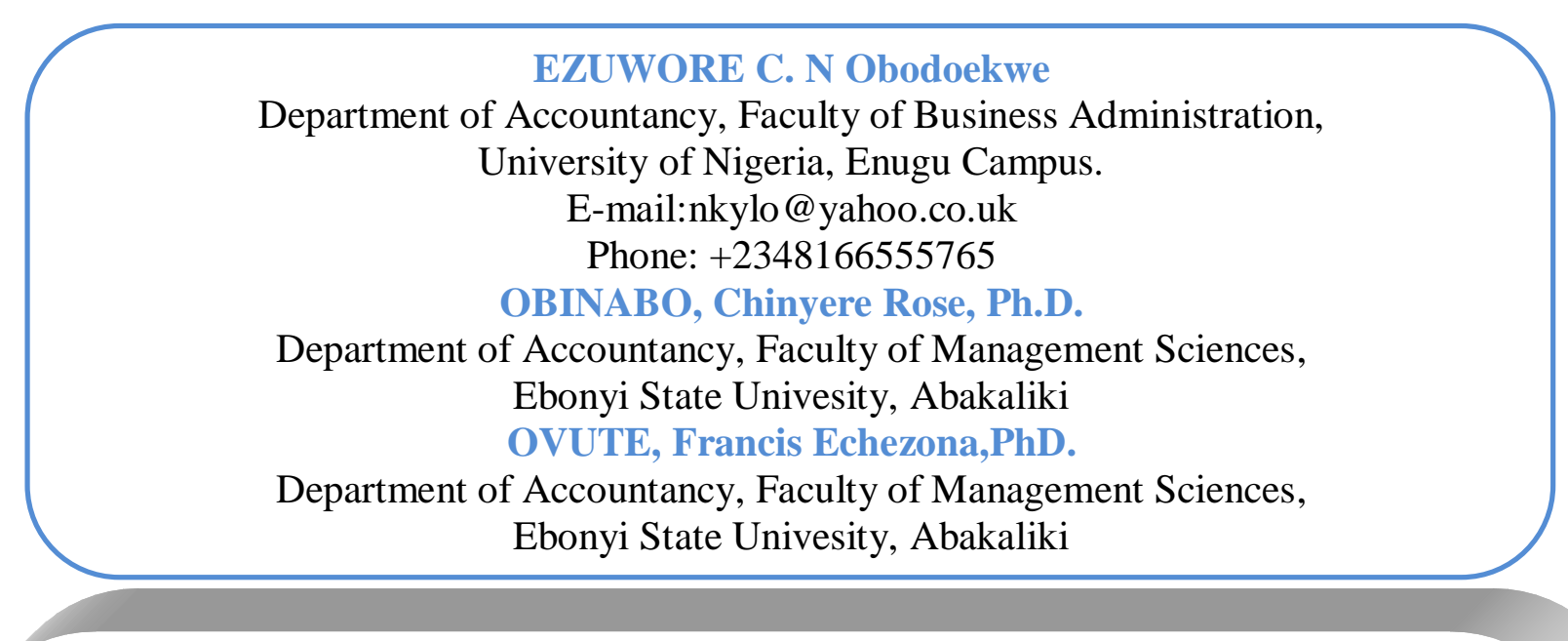

\begin{abstract}
One important function of this paper is to examine the asymmetric effects of monetary policy on output and the role of bank-lending behaviour. The investigation was whether contractionary and expansion policies have symmetric impacts on bank loans, and whether there are further differences in the response of small banks and big banks to policy action. The investigation was also on the link between changes in bank lending and aggregate economic activity. The goal is to simultaneously capture the existence of the lending view of the monetary transmission mechanism, the strong relationship between loan growth and output growth. To access the quality services offered by bank, Access Bank Plc. The research made use of both primary and secondary sources of data. The data analysis used is made of tables, percentages and chi-square techniques was also used in testing hypothesis. From the analysis of data it was discovered that effective of monetary policy are indispensable as far as bank lending is concerned. As this will help in the development of bank's business portfolios. It is the researcher's opinion that if all the recommendations are implemented, it will reduce the frequent cases of distressed situation in the banking industry.

Keywords:Monetary policy,Institutional environment, Bank Lending, Nigeria
\end{abstract}

\subsection{Introduction}

Monetary policy in Nigeria has been conducted under wide range of economic environments since the establishment of the Central Bank of Nigeria (CBN) over thirty years ago. Moreover, in recent years, the federal Government has made conscious and determined efforts to set and attain a high level standard effort of economic aggregates in order to highlight the effect of monetary policy and institutional environment on bank lending in Nigeria.

According to Ikechukwu (1989), he views monetary policy as a deliberate measures fashioned by Government to regulates and control the volume of money in the economy and its cost to borrowers via interest rate, so as to achieve some specified macro economic goals. The banking industry which constitutes the financial sector plays an important role inpromoting economic growth and development through the process of financial intermediation. 
Furness, (1975), views monetary policy as a policy which aims at influencing economic activity by variation in the supply of money, availability of credit or interest rate. In other words, monetary policy is concerned with the control of the availability of credit relative to demand, volume of money for the purpose of achieving certain broad economic objectives.

In essence, right from the formative years of CBN to present times of stringent monetary control, monetary policy has become a veritable means of achieving aggregate economic potentials. In the specific environment of 1970's the main objectives of monetary policy were the maintenance of relative stability and healthy balance of payment position as well as the acceleration of the pace of economic development. Generally, the control of monetary policy depends on the use of direct ceilings, the use of market instruments such as Open market operation (OMO). The issue to be examined in this study is ascertaining the impact, these policies have had on commercial banks, especially (Access Bank Plc) lending, showing the use of economic indicators and their outstanding signals.

The study intends to identify the ways through which monetary policy effects are felt on the institutional environments by commercial banks (Access Bank Plc) lending in Nigeria. In essence, the study hopes to review the nature of various monetary policy instrument.

Bank lending (bank advance) is defined by business Dictionary as a specified sum of money lent by a bank to a customer, usually, for a specified time, at a specified rate of interest. In most cases banks requires some form of security for loans, especially if the loan is to a commercial enterprise. It now becomes the responsibility of the banks or the central Bank of Nigeria to formulate policies that will be adequate andeffective in regulating the terms and conditions of this bank lending. Therefore, Access banks Plc should in accordance with these stated guidelines from the central bank of Nigeria focus on strengthening the effective of these policies.

Finally, the study aims at finding the possible defaults in giving out commercial bank loan and at finding solutions to identified problems and making recommendations where possible.

\subsection{STATEMENT OF PROBLEMS}

Whenever the issues of bank lending is discussed, what really comes to mind is whether these banks are meeting up to the demand of various people that may need their services (customers). If not, what should be responsible for this, and another is what are the ways to solve such problems.

There are problems that triggered us to go into this research. To mention but a few.

a. The issue that money and capital markets are underdeveloped. These markets

lack bills, stocks and share which limit the success of monetary policy.

b. Lack of banking habit among the populace.

c.Non bank financial institutions that are not under the full control of monetary authority.

e.The ineffectiveness and poor implementation of the various policy measures.

f.The persistent increasing rate of inflation in the Nigeria economy.

In an attempt to arrest this unfavourable situation in the banking sector, the researcher has set out to study the current services of the commercial banks in question. Access Bank Plc lending.

\subsection{OBJECTIVES OF THE STUDY}

The objectives of this study are as follows:

\section{Economic Growth}

This means both qualitative and quantitative increase in goods and services produced in the economy annually. Monetary policy promotes growth by creating conducive environment for saving and investment, and effective/efficient use of scarce resources. 


\section{Price Stability}

Moderation of inflation rate has always been one of the major objectives of monetary policy in Nigeria.

Jhingan, (1977), views price stability as economist and a layman alike, which he said favours the policy of price stability because fluctuations in price brings uncertainties and instability into the economy.

\section{Balance of Payment Equilibrium}

Cohen, (1969), defined it as it shows a country trading position as foreign lenders or borrowers, and changes in it's official reserve holding. (Nwankwo, 1977), defined balance of payment equilibrium relating to a country's trading transactions with the outside world. That is to reduce the pressure on the balance of payment.

4.To carry out an investigation on the implementation of monetary policy in Nigeria.

\subsection{RESEARCH QUESTIONS}

In accordance, these research questions, which will help to highlight the performance on monetary policy of commercial bank (Access Bank Plc) lending in Nigeria.

a. Has monetary policies been able to actualise the position in the portfolio management of commercial banks in Nigeria?

b. Has the sectoral allocation of loans been desirable?

c. Do banks lend enough money on the aggregate in accordance with monetary policies?

\subsection{HYPOTHESES FORMATION}

A hypothesis is a provisional statement given to guide an investigation. It is an intelligent guess of an answer to aproblem. A good hypothesis must be stated clearly and concisely to test the relation of difference between variable in operational and measurable terms.

For the purpose of this study to be achieved, the following Null and Alternative hypothesis have been formulated.

1. $\mathrm{H}_{0}:$ Monetary policy and it's institutional environment do not play a significant tolet in ensuring the achievement of micro and macro-economic objective in Nigeria.

$\mathrm{H}_{\mathrm{i}}$ :Monetary policy and it's institutional environment play a significant role in ensuring the achievement of micro and macro-economic objective in Nigeria.

2. $\mathrm{H}_{\mathrm{o}}$ :Monetary policy and it's institutional environment do not maintain relative stability and healthy balance of payment position.

$\mathrm{H}_{\mathrm{i}}:$ Monetary policy and it's institutional environment maintain relative stability and healthy balance of payment position.

\subsection{SIGNIFICANCE OF THE STUDY}

Considering the indispensable roles which the commercial banks play in giving loan services, the significance of this study cannot be overemphasized. This study is envisaged to be of out most important for it's attempt to examine the conceptual and practical problems, exposing the possible difficult challenges encountered in the mechanism of bank lending in commercial banks (Access Bank Plc) included in it's monetary policy in Nigeria. Therefore, it will be vital to address some issues that may occur in the causes giving out this loan.

\section{a. Commercial Banks}

By a proper application of this work, commercial banks, especially Access Bank Plc will be able to identify the favourable policies that will better their lending services to their various customers. 


\section{b. Professional}

This work will be of a great help to both stock brokers and other related areas that has to deal with lending services to carry out their business effectively.

\section{c. The Researcher}

It will expand our horizon and add to the repertoire of knowledge. Which South African investors had established in 1995 and re-organized in 2011 September. Access Bank opened a subsidiary in freetown, Sierra Leone, and then in October, the bank opened subsidiaries in Lusaka, Zambia and in London, United Kingdom.

Finbank (Burumdi) in the year 2009 joined the Access Bank network. Access Bank in 2011 had a talk with the central Bank of Nigeria to acquire intercontinental Bank Plc. Further to the approval of the shareholders of both banks, court section of the Federal High Court of Nigeria and approval of the Central Bank of Nigeria and the Securities and Exchange Commission. Access Bank Plc ("Access") and intercontinental Bank Plc ("Intercontinental Bank") announced the completion of the re-capitalization of intercontinental Bank and the acquisition of $75 \%$ majority interest in intercontinental Bank by Access Bank Plc, Access Bank in January 2012 announced the conclusion of its acquisition of the former intercontinental Bank, creating an expanded Access Bank, one of the largest four commercial banks in Nigeria with over 5.7 million customers, 309 branches and over 1.600 Automated Teller machines (ATMs).

The new management of this bank articulated a transformation agenda for Access Bank Plc. This agenda represented a complete department from all that characterised the bank in the past and became the road map for the transformation of the bank into a world class financial institution. The focus was to:

1. Assemble a credible and high calibre management team.

2. Introduce a culture of excellence founded on professionalism and integrity.

3. To ensure human capital development

4. Enlarge shareholders Base

5. Introduce strong procedure and processes to done day to day activities of the Bank.

6. Instill a passion for customers in all members of staff.

\subsection{REVIEW OF RELATED LITERATURES}

\subsection{THE NATURE OF MONETARY POLICY THEORY}

In recent years, monetary policy theory has been in a very high regards due to the fact that monetary policy plays a crucial role in molding the economic character of a country. This is because money and credit in a modern economy exercises vital influence upon the course native and volume of economic activities.

Falegan, (1978), said that monetary policy deals with the discretionary control of money supply by the monetary authorities in order to achieve stated or desired economic goal. Therefore, an appropriately conceived monetary policy can significantly aid economic growth by adjusting the money supply to the needs of desired productive channels and by making institutional credit arrangement for the specific fields of economic pursuit.

Nevertheless, it must be noted that authorities cannot choose both money supply growth rates independently. The general native of monetary policies open to the monetary authorities are both extreme and continuous. The best idea would be to control both the money supply and interest rates in a price command economy, where the authorities have direct control over the supply of all types of money assets where they can fix the price of borrowed funds and where all private sector institutions lending activities take place only with the approval of the authorities. 
2.2 MONETARY POLICY FORMULATION IN NIGERIA

Akinslire, $(2011$; 324), in opinion States that the Central Bank of Nigeria (C.B.N) is the apex regulatory authority of the financial system in the country that also formulate monetary policy in Nigeria. It was established by the C.B.N Act of 1958 and commenced operations on July $1^{\text {st }}$ 1951.

The promulgation of the CBN decree 24 and Bank and other financial Institutions (Bofi) decree 25, both in 1991 gave the bank more flexibility in regulating and supervision of the banking sector and licensing financial companies which hitherto operation outside any regulatory framework. The process of monetary policy formulation encourages individuals from every sector, of the economy to submit proposals for policy formulation. Every sector, example Government parastatals institutions and other interest groups have an equal chance of submitting their proposal either to their bankers, the Central Bank or the Federal Ministry of finance while others submit personally to the president, these proposals are then submitted to the central Bank of Nigeria or indirectly as the sole authority for monetary policy. After the policy has been studied, scrutinized and approved by the board, it is transmitted to the presidency of Federal Executive

Council in consonance with the government vague. Therefore, it is the duties of the CentralBank to implement the monetary policy approved by the president.

\subsection{MONETARY POLICY IN NIGERIA}

The recapitalization of $\mathrm{N} 25$ billions capital base recommended by the Central Bank of Nigeria $(\mathrm{CBN})$ in banking sector in the monetary development to create efficiency in commercial banking lending (Access Bank Plc). It is a reformation on credit creation. The Central Bank of Nigeria announced a reduction in their inflation rate. According to the Central Bank of Nigeria, the pressure of prices has moderated for sometime, a situation which has helped to stem the rising inflation rate.

Access bank Plc, the bank was incorporated as a private limited liability company and obtained licenses to carry on the business on May 11, 1989 at its Burma Road, Apapa Head Office. In order to meet up to the CBN directives, Access bank

Plc began to raise capital by approaching the capital market through public placements. They engaged in consolidation with other banks (through mergers and acquisition) which invariably trimmed the number of banks in the country.

The banking industry has over the past 2 years witnessed an unprecedented level of growth and expansion on all frontiers. The banks are now able to compete with foreign banks and are able to consummate several large ticket transactions due to a much large resources base and access to liquidity and capital.

\subsection{MONETARY POLICIES ADMINISTRATION IN NIGERIA}

A principal function of the Central Bank of Nigeria is the formulation and execution of monetary policy to promote monetary stability and a sound financial system of Nigeria. This responsibility is carried out on behalf of the Federal Government of Nigeria, through aprocess outlined in the Central Bank ofNigeria decree 241991 (CBN) and the Banks and other financial institutions Decree 25, 1999 (Bofio).

In formulating and executing monetary policy, the government of the Central Bank of Nigeria is required to make proposals to the president of the Federal Republic of Nigeria who had the power to accept or amend such proposal. Monetary Policy Measures are usually announced by the government functionary and must be emphasized that no single individual or institution alone makes monetary policies in the country.

In spite of all, the challenges Nigeria Banks are facing are the increase in the regulatory framework. The CBN has introduced a number of risk focused regulations and a code of 
corporate governance which is forcing banks to adopt best practices of corporate governance, risk management and brand management to ensure sustainability and enhanced value for their shareholders. Another of its kind is how banks will rein in huge resources existing outside the financial sector (estimated to be about $80 \%$ of money supply) in the next few years. Equity Research Report 30th July, 2008.

\subsubsection{Basic Principles of Lending}

Commercial banks (Access Bank Plc) are generally set up to provide avenues for saving to those who have surplus funds. The bulk of such funds are then lent out to needy personnel and business customers in loans and overdrafts. As lending appears to be one of the most intricate services provided by banks, we shall examine the basic principles of bank lending in earnest.

Matter, (1977) a banking author and a great renown and an expert in the practical aspects of banking, compares the principles of lending to economic laws "in that certain facts and other things being equal a prescribed course should follow.

They are neither independent nor unbreakable; This, the principles must be weighted carefully. The three basic principles behind all bank lending, as recommended by matter (1977), but which should serve only as guide are as follows:

1. Safty

2. Suitability

3. Profitability

\section{Safty}

The safty of Access Bank loan advance is of paramount importance to theBank. Hence the bank lays great emphasis on character, integrity and reliability of borrowers. There must be a reasonable certainty that the amount granted can be repaid from the profits and cash flow generated for the operation of the company. If the advance is granted to a personal borrower, the service of repayment must not be doubtful. In support of the safty requirement, the borrower must be able to provideacceptable security which will serve as something to fall back on, if the expected source of repayment should fail.

\section{Suitability}

The banker should also satisfy himself about the suitability of an advance. Even where the requirements of a borrower satisfy all safty and risk considerations, it is absolutely necessary for thebanker to ensure that the purpose of the loan is not in conflict with the economic and monetary policies of the government. There are certain ventures that are not encouraged by bankers; for instance a banker is not expected to lend to finance gambling, betting and other speculations. Commercial banks would also not usually provide long-term capital or equity.

\section{Profitability}

It is a well known facts that banks are business established mainly to make profit and not as charitable organization, therefore, any facilities granted are expected to yield some profit to the bank.

\subsubsection{Canons of Lending}

The three basic principles of lending can be further broken down into other factors, which must be considered when granting an advance either individually or sector wise. Banks have to exercise care and prudence in their lending activities which is described as the canons of lending and they are;

1. How much does the customer or sector want to borrow?

2.Why does the customer or sector want bank finance and what does he/she want it for? 
3.How long does the customer want it for?

4.How long does the customer intend to pay back?

5.Is the customers business financially strong enough to keep going if the plans suffer a set back?

6. What security can the customer itself offer?

\section{a. Amount}

The customer or sector is expected to be able to determine fairy accurate how much finance he or she requires. The capital resources of the borrower will also have to be determined.

\section{b. $\quad$ For How Long}

Banks are basically interested in short term finance because most of its deposits are repayable on demand or at short notice.

\section{c. How does the Customer Intend to pay Back?}

The repayment lies at the heart of any proposition before a bank manager or lending officer, if the customer can demonstrate how and when repayment is to be made.

\section{d. The strength of the Business}

The balance sheet and profit and loss accounts for at least 3 years must be submitted, including the current and projected cash budget should be carefully and compare the statement and figures with the trend shown in the accounts of the customer.

\subsection{BUSINESS PORTFOLIO OF ACCESS BANK PLC}

Access Bank of Nigeria Plc offers the following services to their numerous customers.

1. Collection of deposits

2. Extension of credit facilities (lending)

3. Funds management

4. Safe keeping of valuables

5. Brokerage services

6. Financing of foreign trade

7. Equipment leasing

\subsubsection{Collection of Deposits}

Access Bank Plc offers three main accounts to its customers saving deposit account Demand deposit (current)

account, and Time (fixed) deposit account.

\section{Savings Accounts}

According to Adekanye (1986; 38), savings accounts attract interest at a fixed rate, but funds can be withdrawn at any time without notice. This kind of deposit has no definite maturity date. The savings deposit requires the depositor to make visit to the bank and fill the withdrawal forms by himself before payment is made.

\section{Demand Deposit Accounts}

Demand deposits include all such deposits payable on demand. They are withdrawn by cheque and usually no notice is given to the bank before withdrawal is made Emekekwue $(1994 ; 235)$ contrary to the savings deposit account, it is not compulsory that the customer must present the cheque at the counter by himself, a mere instruction to the bank to pay by writing out his cheque to the amount he wishes to withdraw is enough for the bankto effect the payment. 


\section{Fixed Deposit Accounts}

The fixed deposit include all such deposit that a definite maturity date and an agreed interest rate which is stipulated in the fixed deposit certificate. Adeikanye (1986) p.38 is of the opinion that this account is relatively easy to operate because it neither requires a cheque book nor represented to open it. He further stresses that it is also possible to open fixed deposit accounts for 3,6, 9 months or 1 year. They are called time deposit accounts and they attract higher interest rates but the are expected to be kept for the fixed period time.

\subsubsection{Extension of credit Facilities (lending)}

According to Akpala (1993) p.3, the primary function of commercial banks (Access bank Plc.) is the extension of credit to worthy customers. Adekanye (1986) 0.173 , is of the view that by making credit available commercial banks are rendering a great social services through their actions; production is increased, expansion of capital investments, and there will be a higher standard of living in the society.

In his own contribution, Anyanwaokoro (1996) p.167, maintains that lending is the most important function as far as banks are concerned. He said that other functions which commercial banks perform are more or less incidental to the lending function. According to Anyanwaokoro (1996), the two basic forms of lending are overdraft and loans. Access bank Plc. offers credit facilities to their customers through overdraft and loans.

\subsubsection{Fund Management}

Webster's tweenth New Collegiate Dictionary defines Management as the conducting or supervising of something (asbusiness), or judicious use of means to accomplish an end.

Akpala (1993) p.3, sees management as the process of conbining and utilizing, or collocating an organizations inputs (men, materials, and money) by planning, organising, directing and controlling for the purpose of producing outputs (good and services or whatever the object are) desired by customer so that the organization can achieve their objectives.

Going by the meaning of management above, find management is a situation where the fund deposited in the bank by many customers are efficiently and effectively supervised to take care of the over and or under liquidity. A trade off between these two of them is always maintained, because either of them could pose threats to the bank concerned.

\subsubsection{Safe keeping of Valuables}

Banks usually provides safe-custody services to their customers by virtue of the fact that they have big and strong price proof safes in their strong rooms.

Many customers make use of these facilities by depositing valuable properties such as share certificates, like assurance policies, certificates of occupancy, wills, jewellries and so on in them for saftyAdekanye,(1986) p.180.

\subsubsection{Equipment Leasing}

According to Okafor (1983, p. 250), a lease is a contractual relationship through which the possession, the right to use, and the right to control over an asset is transferred from its bonafide owner to a user in consideration for periodic rental payments. The owner of the property is the lessor, the user as the lease and the periodic rental is called the lease premium. Adekanye (1996), sees equipment (operating lease as a lease under which the lessor maintains and finance the property. It is sometimes called as service leaser. Access bank Plc usually enters into lease contracts with their customers as a way of helping them to finance their investment. 
2.6 TECHNIQUES AND INSTRUMENTS OF MONETARY POLICY MANAGEMENT IN NIGERIA

The instruments of monetary policy are authorities to influence the supply, allocation and cost of credit to the economy. These are also instruments used by the central Bank of a country to change the quantity of availability cost and direction of money and credit on circulation. The instruments are listed bellow

1. The Open Market Operation (OMO)

2. Special Deposits

3. Bank Rate

4. Reserve Requirement

5. Moral Suasion.

Open market operation (OMO). It involves buying and selling of securities in order to influence the cash base and lending power of banks. It has been used by the $\mathrm{CBN}$ its effective use depends on the existence of developed money and capital markets.

Nwankwo 1980)argued that it is the government broker and not the market as such which is crucial to the success or otherwise of open market operation.

\section{Special Deposits}

Banks may called upon to open a separate account quite distinct from cash reserve requirement they normally maintain with the central Bank conversely, the deposit is returned when there is shortage of credit in the economy

\section{Bank Rate}

This is also known as a minimum discount rate and is the rate at which the Central Bank discounts first class Bills for commercial banks. This rate determines the rate charges by commercial banks.

\section{Reserve Requirement}

Under this, we have cash reserve requirement and liquidity requirement ratio. Femi (1986) views Reserve Requirement as a set of minimum balance on the liquidity of commercial bank vis-avis their deposit liabilities. They have two uses.

a.To ensure the solvency of the banking system.

b. Control the expansion of credit creation as an objective of monetary policy.

\section{Moral Suasion}

Adekanya (1986: 130), views moral suasion as simply a process by which the monetary authorities example(Central Bank) make known to commercial; bank in which through informal discussion, the direction in which the monetary policy should proceed and the contribution which is expected on the part of the commercial bank.

Illemonbayo (1997: 180) see moral suasion as the influence which the Central Bank wields over financial system. This tool has been employed on many occasions to tell the banks in clear and unmistakeable terms the direction and nature of policies which the monetary authorities would want them to purpose.

\subsection{THE PROBLEMS EFFECTING BANKS LENDING SERVICE IN NIGERIA}

The question is, are banks in Nigeria effectively giving their loan services to customers? or are they adopting an effective approach in the giving loan services? Accordingly, it should be noted that the lending objective of satisfyingcustomers need is yet to be achieved through banks in Nigeria. This ascertain may be largely due to the problems being encountered daily by the 
banks in their efforts to market their financial services. The following are some of the problems or 3 constraints facing the banks' lending efforts.

\section{Level of Technology Advances.}

The slow and inefficient services rendered by banks can be attributed to the labour intensive nature banking in Nigeria since most of the words are mostly done manually by banks workers. In the advanced countries, the use of computer has added the delivery of quick and efficient services to banks customers. Fortunately, there have recently been an increase in the use of computers by banks in Nigeria. Through, the use of computers will surely help raise the volumes of banks business and also reduce delay. It has some limitation. The technological environment in Nigeria does not permit the efficient use of computer, eg. if difficult to repair it because the required computer expects and technician are not available also, the cost of these computers is very high, making it very impossible for some banks to invest in them.

\section{Problem of Fraud Increase in Banks.}

The alarming increase of frauds in banks now posses a great problem to the banks ability to give loans adequately. These frauds made, foreign of customer signature in order to withdraw illegally from the account, the receiving of bribes by bank managers in order to grant loans and advance for unliable project i.e 10 percent syndrome, the high rate of arbitrary provision for bad debt, and also the collaboration by staff of banks. The level of dishonesty among the banks and the customers is new very high, thereby making it riskier for the bank to market its services.

\subsection{METHODOLOGY}

\subsection{RESEARCH DESIGN}

This word design simply means blue-print or plan on how to go about data collection and analysis, it is all geared towards making available situation to the problem under investigation. However, the main reasons of research design is to obtain data that will enable the researcher to test the pre-set hypothesis or answer research questions of the study (Asika 1991).

This study was carried out using a survey research design, the purpose of using this was because it was seen suitable for this study as it focuses on people, and it also reveal the important facts of people and their beliefs, attitudes, opinions, motivation and behaviour. A well designed questionnaires was administered in the form of face to face interviews and structured questionnaire in the form of close-end, whereby the research has already made the questions in the form of NO,

\subsection{SAMPLE SIZE AND SAMPLING TECHNIQUES}

This is a kind of selecting information or data among a group or population of interest. This is to enable the researcher use the information gotten from the sample size to make overall decision.

The researcher made use of Random Sampling of probability, the indication is that the chance of selecting both senior and junior staff of the bank is equal. This sample size is made of selected group which is to represent the population size. Out of the total population of Access Bank employees and customers Nsukka Branch, thirty (30) was chosen as the sample for this research work. Questionnaires were sent out at the end, all were returned which has good responses in the circumstances

\subsection{METHOD OF DATA COLLECTION}

Method of data collection is a means of collecting data for subsequent measurement of variables, and this will be used to answer the research question or testing hypothesis. Questionnaire was 
used in collecting these data which comprises interviews and other means like the use of library materials.

To make the findings more meaningful, oral interview was used by the researcher. The questionnaires were given to the workers of Access Bank and were collected within the stipulated time.

\subsection{DISCUSSION OF THE FINDINGS}

From the data gathered from the questionnaire and interview with presentation and analysis, the researcher believes that majority of the respondents agree that the effectiveness of monetary policy plays a significant role in the banking sector. From the hypothesis one, it was observed that the effect of monetary policy help in the achievement of micro and macroeconomic objectives. This was proved by the wide gab between the null hypothesis and alternative hypothesis.

Thus, hypothesis two also backed up that the effect of monetary policy in Nigeria commercial banks cannot be over emphasized in granting of loan in the operation of the banking sectors in the economy it was emphasized that monetary policy maintenance relative stability and healthy balance of payment position.

\subsection{FINDINGS, RECOMMENDATION,CONCLUSION \\ 4.1 SUMMARY OF FINDINGS}

The monetary and capital markets are undeveloped, that is, there is lack of stock, and this limit the success of monetary policy, the ineffectiveness and poor implementation of the various policy measure, the persistent increasing rate of inflation in the Nigeria economy.

\subsubsection{Instrument of Monetary Policy}

From the analysis at Table 4.4, 60\% of the respondents agreed that there is an adequate instrument put in place to guide the monetary policies in Nigeria economy, while $40 \%$ do not agree. The adequate instrument put in place to monitor these markets are; open market operation, annual credit guideline, moral suasion, reserve requirements etc.

\subsubsection{Other Bank Services}

Going by the analysis on the bank services, analysis of Table $4.8,70 \%$ of the respondents agreed that other bank loan service apart from bank loan are adequate to aid monetary policies in Nigeria economy, while $30 \%$ do not agree. The other monetary policies are fiscal policy, payment of dividend etc.

\subsubsection{Aims and Objectives of the Bank}

As it was based on another finding, it was to know if monetary policy worked to attain it's aim and objective in Nigeria economy. As one can see from the analysis, $63.3 \%$ of the response agreed that monetary policy attain its aims and objectives, while $36.7 \%$ do not agree. Any from this findings, the aims and objective achieved by monetary policy are; Economic growth, price stability, balance of payment equilibrium etc.

\subsubsection{Commercial Banks Lending}

From the analysis of the findings in Table 4.10, $83.3 \%$ of the respondents agreed that commercial banks perform a vital role in execution of monetary policies in Nigeria, while $16.7 \%$ do not agree. The vital role performed by commercial banks are lending of loan and advances, safeguard of assets, serve as advisory to customers, management of customers investment.

\subsubsection{Survival and Growth}

From the results of the research conducted, it was discovered that the survival and growth of a bank depend immensely on the effectiveness and efficient implementation of the monetary policies adopted by the bank. Therefore, in order to survive in this present competitive banking environment in Nigeria, banks must employ the necessary strategy to make sure that their 
activities are going in accordance with best monetary policies that will bring profitability in the bank.

\subsubsection{Quality of Services}

The quality of service offered by commercial banks has either a positive or negative influence on their performance. From the findings on this cause of this research work, monetary policy adopted by a particular bank has a direct relation on the way they will be rendering their services to customers. so, a good policy adopted will have a positive impact on their performance.

\subsection{RECOMMENDATIONS}

For effective and efficient of loan lending services in banks, the finding in the findings in the study thus form the basis of my recommendations and conclusion, the following recommendations were made.

\section{Credit Guidelines}

Banking sectors should use Central Bank of Nigeria Credit Guidelines to enable them go about loan lending services.

\section{External Reserves}

The management should enhance the maintenance of external reserves in order to safeguard the internal value of the currency.

\section{Implementation of Monetary Policy}

The management should also carry out an investigation on the implementation of monetary policy of Nigeria so that they do not cause errors, problems to their business when giving out loans.

\section{Adequate Instrument}

The Management of the Access Bank Plc should use the adequate instrument of Monetary Policy to enable them promote monetary stability and a sound financial structure.

\section{Research}

Research seeks to find out the conditions or relationship that exist, opinions that are held, processes that are goingon, effects that are evident or trends that are developing. Banks should carry out research to determine the acceptability of proposed services or modifications to existing ones, pre-testing and post-testing of policies. Banks should always go into researching to come up with more sophisticated strategies which can effectively and efficiently meet challenges posed by economic meltdown.

\subsubsection{Recommendations Based on Increasing the Efficiency of Bank Services 1.Manpower Efficiency}

The researcher recommends that all banks improve on the quality of their employees skills as this will help in increasing the efficient and profitability of the bank in question.

\section{Detection of Errors and Frauds}

the alarming increase of frauds in the banks new poses a great problem to banks ability to give loans adequately, banks are therefore adviced to put in place an adequate securities that will help them prevent the alarming increase in the banking activities.

\section{Introduction of Modern Technology}

The slow and inefficient services rendered by banks can be attributed to low level of modern facilities, banks should make adequate provision for modern facilities to facilitate their services; for instance, the use of computers will aid the delivery of a quick and efficient services to bank's customers.

\section{Training of Employees}

Training programmes should always be put in place so as to give the customers the best services. Therefore, banks have to be concerned with effective training of personnelto sell the various services/their lending activities. 


\subsection{CONCLUSION}

The effectiveness of monetary policy and institutional environment on bank lending in Nigeria to be effective, all the instruments of monetary policy must be properly coordinated to ensure that the total effect of all the instruments employed work towards achieving the desired objectives. Because most often, a particular objective cannot be achieved through the employment of just one instrument. The critical issue is to ensure that whether combination of instruments are employed, they must not to contract each other, because when those instruments are in line with Central Bank of Nigeria Regulations, the policy will be effective in banking sectors. The instruments used to achieve this objectives include: Open Market Operation, Moral Suasion, Reserve Requirement, also the use of Annual Credit Guidelines and Special Deposits.

\section{BIBLIOGRAPHY}

1. Falegan S.B. (1978), Instruments of Monetary Policy their Application and Effectiveness in Nigeria. A Paper Presented at the Symposium on the Role of Monetary Policy in Developing Countries, Gambia.

2. Femi Adekanye (1986), The Elements of Banking in Nigeria, 3rd Edition, Lagos: F \& A Publishers Limited.

3. Furness E.L. (1975), Money and Credit DevelopingAfrican.Gambia: Heinemann Limited.

4. Ikechukwu, D.A. (1989), "Implementation of CBN's Monetaryand Credit Policies: An Overview of the Banking System Performance", Business Times, March 20, Vol.4, p. 8.

5. Ilemobayo S.A. (1997), Public Finance in Nigeria: With Questions and Answers. Lagos:Bank Pointing and Publishing Company.

6. Mather L.C. (1977), Banker and Customer Relationship and the Accounts of Personal Customers, 5th Edition, London: Waterlo Limited.

7. OyeAkmsulire (2011), Financial Management, 7th Edition,Lagos: Ceemol Limited. 